\title{
Selective Separation and Recovery of Pt(IV) from Pd(II) through an Imidazolium-ionic-liquid-based Supported Liquid Membrane
}

\author{
Wataru Yoshida, ${ }^{*}$ Fukiko Kubota,* Riho Kono,* and Masahiro Goto*,**† \\ *Department of Applied Chemistry, Graduate School of Engineering, Kyushu University, 744 Motooka, \\ Fukuoka 819-0395, Japan \\ **Center for Future Chemistry, Kyushu University, 744 Motooka, Fukuoka 819-0395, Japan
}

\begin{abstract}
A supported liquid membrane (SLM) system for the selective separation of platinum(IV) from palladium(II) has been developed. The SLM was prepared using imidazolium-based IL 1-octy-3-methylimidazolium bis(trifluoromethanesulfonyl)imide. The initial flux and separation factor of $\mathrm{Pt}(\mathrm{IV})$ from $\mathrm{Pd}(\mathrm{II})$ were found to significantly depend on the composition of the receiving solution. Based on the performance, a $0.1 \mathrm{~mol} \mathrm{dm}^{-3} \mathrm{NaClO}_{4}$ solution was selected as a suitable receiving solution. Membrane transport experiments showed that $93 \%$ of $\mathrm{Pt}(\mathrm{IV})$ can be selectively transported into the receiving solution, whereas most $\mathrm{Pd}(\mathrm{II})$ remains in the feed solution.
\end{abstract}

Keywords Supported liquid membrane (SLM), separation, platinum, imidazolium ionic liquid

(Received August 10, 2018; Accepted October 4, 2018; Advance Publication Released Online by J-STAGE October 12, 2018)

\section{Introduction}

Platinum group metals (PGMs) are essential elements for hightech industries, such as the electronic, chemical, and automobile industries. ${ }^{1}$ The separation and recovery of PGMs from secondary resources and liquid waste from factories has attracted attention for a stable supply of PGMs as well as the prevention of environmental pollution. ${ }^{2}$ However, the separation and sensitive determination of PGMs are generally difficult because of similarities of the chemical and physical properties of PGMs. ${ }^{3}$

Solvent extraction is one of the most effective techniques for the analysis and separation of metal ion(s). ${ }^{4}$ Platinum $(\mathrm{Pt})$ and/or palladium $(\mathrm{Pd})$ extraction using a variety of extractants has been reported. ${ }^{5-10}$ However, the separation of Pt from Pd is still a difficult issue, and more effective analytical methods are required. In addition, solvent extraction causes serious environmental and health issues associated with using toxic organic diluents. ${ }^{11}$

Supported liquid membranes (SLMs) have attracted attention as an efficient method for the separation and preconcentration of target metals. ${ }^{12,13}$ Organic diluents have also been used for SLMs as membrane phases. Several researchers have reported effective SLMs based on ionic liquids (ILs), which are salts with a melting point below $100^{\circ} \mathrm{C} \cdot{ }^{14-18}$ ILs have unique properties, such as high thermal stability, negligible vapor pressure and flame resistance; therefore, they have gained tremendous attention from researchers of separation science. ${ }^{19-23}$ Separation using IL-based SLMs is an attractive green alternative to traditional solvent extraction because an organic solvent is not required. However, Pt transport with IL-based SLMs has not been reported.

† To whom correspondence should be addressed.

E-mail: m-goto@mail.cstm.kyushu-u.ac.jp
PGM extraction using ILs has recently been reported. ${ }^{2430}$ Moreover, in our previous studies, we reported on the selective extraction of $\mathrm{Pt}(\mathrm{IV})$ over $\mathrm{Pd}(\mathrm{II})$ using undiluted imidazoliumbased ILs as the extracting phase..$^{31-33}$ We investigated the effects of the alkyl chain length of the IL cation and the type of partner anion on the extraction performance. 1-Octy-3-methylimidazolium bis(trifluoromethanesulfonyl)imide $\left(\left[\mathrm{C}_{8} \mathrm{mim}\right]\left[\mathrm{Tf}_{2} \mathrm{~N}\right]\right)$ was selected as an optimal IL for the separation of $\mathrm{Pt}(\mathrm{IV})$ from $\operatorname{Pd}(\mathrm{II})$.

In this study, we investigated the selective transport of $\mathrm{Pt}(\mathrm{IV})$ through a SLM with $\left[\mathrm{C}_{8} \operatorname{mim}\right]\left[\mathrm{Tf}_{2} \mathrm{~N}\right]$ as the membrane phase. This is the first report of concerning the efficient and selective separation of Pt(IV) from Pd(II) though a SLM.

\section{Results and Discussion}

A liquid-liquid extraction experiment using $\left[\mathrm{C}_{8} \operatorname{mim}\right]\left[\mathrm{Tf}_{2} \mathrm{~N}\right]$ as the extracting phase was performed to determine the optimal $\mathrm{HCl}$ concentration in the aqueous feed solution for the selective extraction of $\mathrm{Pt}(\mathrm{IV})$. Figure S1 (Supporting Information) shows the extraction behavior of $\mathrm{Pt}(\mathrm{IV})$ and $\mathrm{Pd}(\mathrm{II})$ with $\left[\mathrm{C}_{8} \mathrm{mim}\right]\left[\mathrm{Tf}_{2} \mathrm{~N}\right]$ from their $\mathrm{HCl}$ solutions. The degree of extraction $(E)$ of $\mathrm{Pt}(\mathrm{IV})$ increases with increasing $\mathrm{HCl}$ concentration in the concentration range of $<1 \mathrm{~mol} \mathrm{dm}^{-3}$; it decreases with increasing $\mathrm{HCl}$ concentration for $>1 \mathrm{~mol} \mathrm{dm}^{-3}$ owing to competitive extraction of the $\mathrm{Cl}^{-}$anion. ${ }^{3}$ The maximum $E$ for Pt(IV) (about 68\%) occurs at around $1 \mathrm{~mol} \mathrm{dm}^{-3} \mathrm{HCl}$. Conversely, $E$ of $\mathrm{Pd}(\mathrm{II})$ decreases with increasing $\mathrm{HCl}$ concentration until no $\mathrm{Pd}(\mathrm{II})$ extraction is observed in the range of $1-2 \mathrm{~mol} \mathrm{dm}^{-3} \mathrm{HCl}$. Based on the results, $1 \mathrm{~mol} \mathrm{dm}^{-3}$ was selected as the optimal $\mathrm{HCl}$ concentration in terms of the extraction performance of $\mathrm{Pt}(\mathrm{IV})$ and the selectivity for $\mathrm{Pt}(\mathrm{IV})$ over $\mathrm{Pd}(\mathrm{II})$. As shown in the speciation graphs of $\mathrm{Pt}(\mathrm{IV})$ and $\mathrm{Pd}(\mathrm{II})$ in aqueous $\mathrm{HCl}$ solutions, calculated using the 

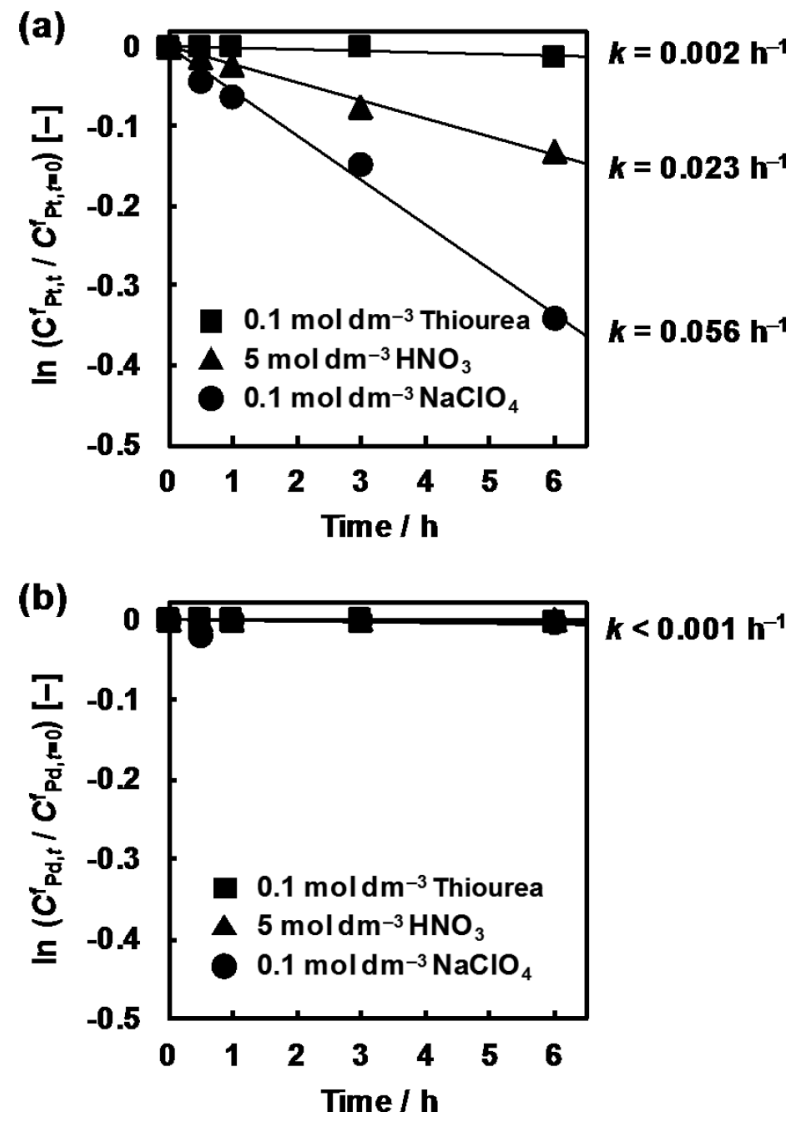

Fig. 1 Kinetic plots of the transport of (a) Pt(IV) and (b) Pd(II) across a $\left[\mathrm{C}_{8} \operatorname{mim}\right]\left[\mathrm{Tf}_{2} \mathrm{~N}\right]$-based SLM. Experimental conditions: feed solution volume and composition, $50 \mathrm{~mL}$ and $50 \mathrm{mg} \mathrm{dm}^{-3}$ each of $\mathrm{Pt}(\mathrm{IV})$ and $\mathrm{Pd}(\mathrm{II})$ in $1 \mathrm{~mol} \mathrm{dm}^{-3} \mathrm{HCl}$; receiving solution volume and composition, $=50 \mathrm{~mL}$ and $0.1 \mathrm{~mol} \mathrm{dm}^{-3}$ thiourea, $5 \mathrm{~mol} \mathrm{dm}^{-3} \mathrm{HNO}_{3}$, or $0.1 \mathrm{~mol} \mathrm{dm}^{-3} \mathrm{NaClO}_{4}$.

corresponding stability constants ${ }^{34,35}$ (Fig. S2), Pt(IV) and Pd(II) mainly form anionic chloride complexes in $>0.01 \mathrm{~mol} \mathrm{dm}^{-3} \mathrm{HCl}$ solution. Therefore, the extraction of $\mathrm{Pt}(\mathrm{IV})$ and $\mathrm{Pd}(\mathrm{II})$ from $1 \mathrm{~mol} \mathrm{dm}^{-3} \mathrm{HCl}$ with $\left[\mathrm{C}_{8} \mathrm{mim}\right]\left[\mathrm{Tf}_{2} \mathrm{~N}\right]$ is assumed to proceed by the anion exchange mechanism..$^{24-26}$

The transport experiments were carried out using the transport apparatus shown in Fig. S3 (Supporting Information). The transport of $\mathrm{Pt}(\mathrm{IV})$ and $\mathrm{Pd}(\mathrm{II})$ from the feed solution through a $\left[\mathrm{C}_{8} \mathrm{mim}\right]\left[\mathrm{Tf}_{2} \mathrm{~N}\right]$-based SLM was investigated using three different receiving solutions: $0.1 \mathrm{~mol} \mathrm{dm}^{-3}$ thiourea $(\mathrm{pH} \mathrm{6.0)}$, $5 \mathrm{~mol} \mathrm{dm}^{-3} \mathrm{HNO}_{3}$, and $0.1 \mathrm{~mol} \mathrm{dm}{ }^{-3} \mathrm{NaClO}_{4}$ (pH 5.5). These solutions are often used for the efficient stripping of $\mathrm{Pt}(\mathrm{IV})$. $^{3,13,30,36}$ The kinetic rate constant, $k\left(\mathrm{~h}^{-1}\right)$, permeability coefficient, $P$ $\left(\mathrm{m} \mathrm{h}^{-1}\right)$, initial flux, $J_{0}\left(\mathrm{~mol} \mathrm{~m} \mathrm{~m}^{-2} \mathrm{~s}^{-1}\right)$, separation factor, $\beta(-)$, and recovery factor, $\mathrm{RF}(\%)$, were calculated using the following equations:

$$
\begin{aligned}
& \ln \left(\frac{C^{\mathrm{f}}{ }_{\mathrm{M}, \mathrm{t}}}{C^{\mathrm{f}}{ }_{\mathrm{M}, \mathrm{t}=0}}\right)=-k t, \\
& P=\left(\frac{V}{A}\right) k, \\
& J_{0}=P C^{\mathrm{f}}{ }_{\mathrm{M}, \mathrm{t}=0},
\end{aligned}
$$

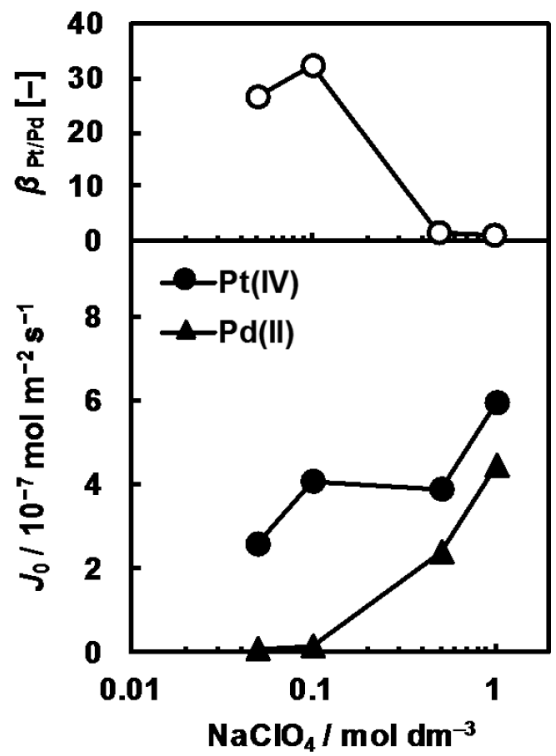

Fig. 2 Effect of the $\mathrm{NaClO}_{4}$ concentration in the receiving solution on the transport of $\mathrm{Pt}(\mathrm{IV})$ and $\mathrm{Pd}(\mathrm{II})$ across the $\left[\mathrm{C}_{8} \operatorname{mim}\right]\left[\mathrm{Tf}_{2} \mathrm{~N}\right]$-based SLM. Experimental conditions: feed solution volume and composition, $50 \mathrm{~mL}$ and $50 \mathrm{mg} \mathrm{dm}^{-3}$ of both Pt(IV) and Pd(II) in $1 \mathrm{~mol} \mathrm{dm}^{-3} \mathrm{HCl}$; receiving solution volume and composition, $50 \mathrm{~mL}$ and $0.05-1 \mathrm{~mol}$ $\mathrm{dm}^{-3} \mathrm{NaClO}_{4}$.

$$
\begin{aligned}
& \beta=\frac{J_{0, \mathrm{Pt}}}{J_{0, \mathrm{Pd}}}, \\
& \mathrm{RF}=\frac{C^{\mathrm{r}}{ }_{\mathrm{M}, \mathrm{t}}}{C^{\mathrm{f}}{ }_{\mathrm{M}, \mathrm{t}=0}} \times 100,
\end{aligned}
$$

where $t$ is time $(\mathrm{h}) ; C_{\mathrm{M}, \mathrm{t}=0}$ and $C_{\mathrm{M}, \mathrm{t}}$ are the concentrations of the metal ion $\left(\mathrm{mol} \mathrm{m}^{-3}\right)$ at $t=0$ (original solution) and $t$ (extraction time), respectively. $V\left(\mathrm{~m}^{3}\right)$ is the volume of the feed solution and $A\left(\mathrm{~m}^{2}\right)$ is the effective membrane area. Superscripts $f$ and $r$ denote the feed and receiving solution, and subscripts Pt and Pd refer to platinum and palladium. The $k$ value was obtained as the slope of $\ln \left(C_{\mathrm{M}, t}^{\mathrm{f}} / C_{\mathrm{M}, \mathrm{t}=0}^{\mathrm{f}}\right)$ versus $t$.

The concentration of $\mathrm{Pt}(\mathrm{IV})$ in the feed solution decreased with time, and that in the receiving phase increased simultaneously, although it was only slightly transported during the operation time $(6 \mathrm{~h})$ in the case using thiourea. $\mathrm{Pd}(\mathrm{II})$ is hardly transported during the same period in each case. Plots of $\ln \left(C_{\mathrm{M}, \mathrm{f}}^{\mathrm{f}} / C_{\mathrm{M}, \mathrm{t}=0}^{\mathrm{f}}\right)$ versus time are shown in Fig. 1 , and the corresponding rate constants $(k)$ obtained from the slopes of the plots are given in Fig. 1. For $\mathrm{Pt}(\mathrm{IV})$, the highest $k$ was obtained using $\mathrm{NaClO}_{4}$ solution, and the effect of the $\mathrm{NaClO}_{4}$ concentration in the receiving solution was investigated.

The initial flux of each metal $\left(J_{0}\right)$ and the separation factor $(\beta)$ for different $\mathrm{NaClO}_{4}$ concentrations in the receiving solution are shown in Fig. 2. The initial flux of $\mathrm{Pt}(\mathrm{IV})$ increases with increasing concentration of $\mathrm{NaClO}_{4}$ in the range of $0.05-1 \mathrm{~mol}$ $\mathrm{dm}^{-3}$. A higher concentration of $\mathrm{NaClO}_{4}$ in the receiving solution facilitates the transport of $\mathrm{Pt}(\mathrm{IV})$. The initial flux of $\mathrm{Pd}(\mathrm{II})$ is nearly zero in the range of $0.05-0.1 \mathrm{~mol} \mathrm{dm}^{-3}$ $\mathrm{NaClO}_{4}$, and then increases with increasing $\mathrm{NaClO}_{4}$ concentration above $0.1 \mathrm{~mol} \mathrm{dm}^{-3}$ because of an increase in the stripping efficiency for $\mathrm{Pd}(\mathrm{II})$. A high concentration of $\mathrm{ClO}_{4}^{-}$ may lead to anion exchange with the ionic liquid anion. Owing to this trend, the separation factor between $\mathrm{Pt}(\mathrm{IV})$ and $\mathrm{Pd}(\mathrm{II})$ is highest at $0.1 \mathrm{~mol} \mathrm{dm}^{-3} \mathrm{NaClO}_{4}$. Based on the performance, 


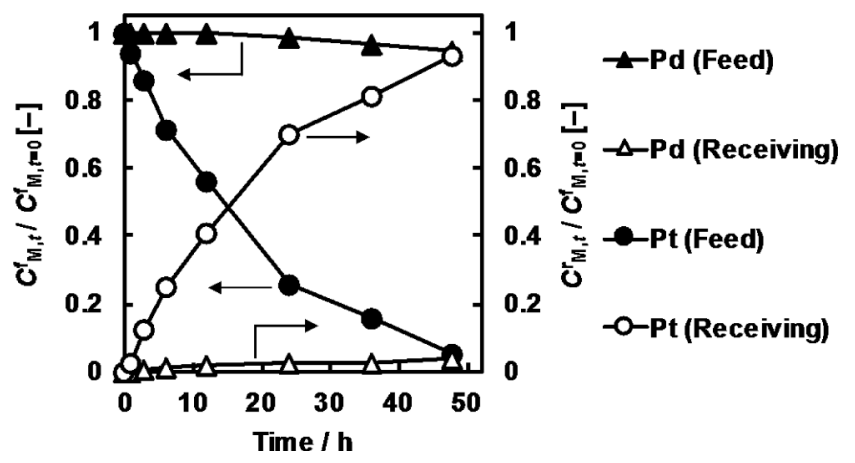

Fig. 3 Transport of $\mathrm{Pt}(\mathrm{IV})$ and $\mathrm{Pd}(\mathrm{II})$ across the $\left[\mathrm{C}_{8} \operatorname{mim}\right]\left[\mathrm{Tf}_{2} \mathrm{~N}\right]-$ based SLM. Experimental conditions: feed solution volume and composition, $50 \mathrm{~mL}$ and $50 \mathrm{mg} \mathrm{dm}^{-3}$ of both $\mathrm{Pt}(\mathrm{IV})$ and $\mathrm{Pd}$ (II) in $1 \mathrm{~mol} \mathrm{dm}^{-3} \mathrm{HCl}$; receiving solution volume and composition, $50 \mathrm{~mL}$ and $0.1 \mathrm{~mol} \mathrm{dm}^{-3} \mathrm{NaClO}_{4}$.

Table 1 Kinetic parameters for the transport of $\mathrm{Pt}(\mathrm{IV})$ and $\mathrm{Pd}(\mathrm{II})$ across the $\left[\mathrm{C}_{8} \mathrm{mim}\right]\left[\mathrm{Tf}_{2} \mathrm{~N}\right]$-based SLM (thickness $125 \mu \mathrm{m}$ ) (experimental conditions same as in Fig. 3).

\begin{tabular}{ccccc}
\hline Metal ion & $k / \mathrm{h}^{-1}$ & $P / \mathrm{m} \mathrm{h}^{-1}$ & $C_{\mathrm{M}, \mathrm{t}=0}^{\mathrm{f}} / \mathrm{mol} \mathrm{m}^{-3}$ & $J_{0} / \mathrm{mol} \mathrm{m}^{-2} \mathrm{~s}^{-1}$ \\
\hline $\mathrm{Pt}(\mathrm{IV})$ & $5.6 \times 10^{-2}$ & $5.7 \times 10^{-3}$ & 0.262 & $4.1 \times 10^{-7}$ \\
$\operatorname{Pd}(\mathrm{II})$ & $9.0 \times 10^{-4}$ & $9.2 \times 10^{-5}$ & 0.492 & $1.3 \times 10^{-8}$ \\
\hline
\end{tabular}

$0.1 \mathrm{~mol} \mathrm{dm}{ }^{-3}$ was selected as the optimal $\mathrm{NaClO}_{4}$ concentration in the receiving solution.

Figure 3 shows the transport behavior of $\mathrm{Pt}(\mathrm{IV})$ and $\mathrm{Pd}(\mathrm{II})$ from the feed to the receiving solution using the $\left[\mathrm{C}_{8} \mathrm{mim}\right]\left[\mathrm{Tf}_{2} \mathrm{~N}\right]-$ based SLM. Pt(IV) is selectively transported from the feed to the receiving solution, contrary to its apparent concentration gradient, whereas $\mathrm{Pd}(\mathrm{II})$ is only slightly transported during the same period. The recovery factors of $\mathrm{Pt}(\mathrm{IV})$ and $\mathrm{Pd}(\mathrm{II})$ using the SLM are 93 and $4 \%$ at $48 \mathrm{~h}$, respectively. Based on the plot of $\ln \left(C_{\mathrm{M}, t}^{\mathrm{f}} / C_{\mathrm{M}, \mathrm{t}=0}^{\mathrm{f}}\right)$ versus time shown in Fig. 1, the kinetic parameters for $\mathrm{Pt}(\mathrm{IV})$ and $\mathrm{Pd}(\mathrm{II})$ were calculated, and are summarized in Table 1. These results show the potential of the SLM for the selective separation of $\mathrm{Pt}(\mathrm{IV})$ from an aqueous solution also containing Pd(II).

\section{Conclusions}

We have reported an IL-based SLM for the selective separation of $\mathrm{Pt}(\mathrm{IV})$ from $\mathrm{Pd}(\mathrm{II})$ in a $\mathrm{HCl}$ solution. The SLM with $\left[\mathrm{C}_{8} \mathrm{mim}\right]\left[\mathrm{Tf}_{2} \mathrm{~N}\right]$ as the membrane phase allows the selective transfer of Pt(IV) from a feed solution to a $0.1 \mathrm{~mol} \mathrm{dm}^{-3} \mathrm{NaClO}_{4}$ receiving solution against the concentration gradient, whereas most of the $\mathrm{Pd}(\mathrm{II})$ is remains in the feed solution. The results show that the developed a SLM system is effective for the separation of $\mathrm{Pt}(\mathrm{IV})$ from a mixture also containing $\mathrm{Pd}(\mathrm{II})$ in such applications as industrial and analytical fields.

\section{Acknowledgements}

This work was supported by a Grant-in-Aid for Scientific Research (No. JP16K06830) from the Ministry of Education, Science, Sports, and Culture of Japan and the Environment Research and Technology Development Fund (ERTDF, Grant
No. 3-1710), Ministry of the Environment, Japan. W. Yoshida is grateful to JSPS for a Research Fellowship for Young Scientists (Grant No. 17J04900). We thank Edanz Group (www. edanzediting.com/ac) for editing a draft of this manuscript.

\section{Supporting Information}

Experimental details, extraction behavior of metals using $\left[\mathrm{C}_{8} \mathrm{mim}\right]\left[\mathrm{Tf}_{2} \mathrm{~N}\right]$, speciation graphs of the chloride complexes and schematic diagram of the SLM transport system are in Supporting Information. This material is available free of charge on the Web at http://www.jsac.or.jp/analsci/.

\section{References}

1. F. L. Bernardis, R. A. Grant, and D. C. Sherrington, React. Funct. Polym., 2005, 65, 205.

2. M. Iwakuma, T. Ohshima, and Y. Baba, Solvent Extr. Res. Dev., Jpn., 2008, 15, 21.

3. W. Yoshida, Y. Baba, F. Kubota, N. Kamiya, and M. Goto, J. Chem. Eng. Jpn., 2017, 50, 521.

4. A. M. Wilson, P. J. Bailey, P. A. Tasker, J. R. Turkington, R. A. Grant, and J. B. Love, Chem. Soc. Rev., 2014, 43, 123.

5. H. Narita, M. Tanaka, K. Morisaku, and T. Abe, Chem. Lett., 2004, 33, 1144.

6. J. R. Kumar, J. Lee, J. Kim, and J. Sohn, Solvent Extr. Res. Dev., Jpn., 2009, 16, 13.

7. Y. Baba, Y. Kanai, S. Kanemaru, and T. Oshima, Solvent Extr. Res. Dev., Jpn., 2010, 17, 195.

8. M. K. Jha, D. Gupta, J. C. Lee, V. Kumar, and J. Jeong, Hydrometallurgy, 2014, 142, 60.

9. Y. Ueda, S. Morisada, H. Kawakita, and K. Ohto, Solvent Extr. Res. Dev., Jpn., 2014, 21, 9.

10. M. Maeda, H. Narita, C. Tokoro, M. Tanaka, R. Motokawa, H. Shiwaku, and T. Yaita, Sep. Purif. Technol., 2017, 177, 176.

11. X. J. Yang, A. G. Fane, and K. Soldenhoff, Ind. Eng. Chem. Res., 2003, 42, 392.

12. J. Fu, S. Nakamura, and K. Akiba, J. Membr. Sci., 1995, 107, 283.

13. C. Fontàs, R. Tayeb, S. Tingry, M. Hidalgo, and P. Seta, J. Membr. Sci., 2005, 263, 96.

14. L. C. Branco, J. G. Crespo, and C. A. M. Afonso, Angew. Chem. Int. Ed., 2002, 41, 2771.

15. E. Miyako, T. Maruyama, N. Kamiya, and M. Goto, Chem. Commun., 2003, 2926.

16. M. Matsumoto, Y. Inomoto, and K. Kondo, J. Membr. Sci., 2005, 246, 77.

17. F. Kubota, Y. Shimobori, Y. Koyanagi, K. Shimojo, N. Kamiya, and M. Goto, Anal. Sci., 2010, 26, 289.

18. Y. Baba, F. Kubota, N. Kamiya, and M. Goto, Solvent Extr. Res. Dev., Jpn., 2011, 18, 193.

19. X. Han and D. W. Armstrong, Acc. Chem. Res., 2007, 40, 1079.

20. N. Hirayama, Solvent Extr. Res. Dev., Jpn., 2011, 18, 1.

21. Y. Baba, F. Kubota, N. Kamiya, and M. Goto, J. Chem. Eng. Jpn., 2011, 44, 679.

22. F. Kubota, Y. Baba, and M. Goto, Solvent Extr. Res. Dev., Jpn., 2012, 19, 17.

23. M. Atanassovs, H. Okamura, A. Eguchi, Y. Ueda, T. Sugita, and K. Shimojo, Anal. Sci, 2018, 34, 973.

24. S. Génand-Pinaz, N. Papaiconomou, and J.-M. Leveque, Green Chem., 2013, 15, 2493. 
25. T. Kakoi, M. Kawagoe, and M. Goto, J. Chem. Eng. Jpn., 2014, 47, 666.

26. Y. Tong, C. Wang, Y. Huang, and Y. Yang, Ind. Eng. Chem. Res., 2015, 54, 705.

27. N. Papaiconomou, L. Svecova, C. Bonnaud, L. Cathelin, I. Billard, and E. Chainet, Dalton Trans., 2015, 44, 20131.

28. S. Ma, K. Funaki, A. Miyazaki, A. Muramatsu, and K. Kanie, Chem. Lett., 2017, 46, 1422.

29. W. Liu, Q. Wang, Y. Zheng, S. Wang, Y. Yan, and Y. Yang, Dalton Trans., 2017, 46, 7210.

30. M. L. Firmansyah, F. Kubota, and M. Goto, J. Chem. Technol. Biotechnol., 2018, 93, 1714.
31. J. Yang, F. Kubota, Y. Baba, N. Kamiya, and M. Goto, Solvent Extr. Res. Dev., Jpn., 2014, 21, 89.

32. J. Yang, F. Kubota, Y. Baba, N. Kamiya, and M. Goto, Solvent Extr. Res. Dev., Jpn., 2014, 21, 129.

33. F. Kubota, E. Shigyo, W. Yoshida, and M. Goto, Solvent Extr. Res. Dev., Jpn., 2017, 24, 97.

34. S. Alerasool, D. Boecker, B. Rejai, R. D. Gonzalez, G. del Angel, M. Azomosa, and R. Gomez, Langmuir, 1988, 4, 1083.

35. L. I. Elding, Inorg. Chim. Acta, 1972, 6, 647.

36. S. Katsuta, Y. Yoshimoto, M. Okai, Y. Takeda, and K. Bessho, Ind. Eng. Chem. Res., 2011, 50, 12735. 